\title{
Performance Evaluation of Humanities and Social Sciences Scholarship Programs in the Thai Higher Education System
}

\author{
Ungsinun Intarakamhang, Sudarat Tuntivivat* \\ Behavioral Science Research Institute, Srinakharinwirot University, 114 Sukhumvit 23, Wattana, Bangkok, Thailand
}

Received February 8, 2021; Revised April 6, 2021; Accepted May 16, 2021

\section{Cite This Paper in the following Citation Styles}

(a): [1] Ungsinun Intarakamhang, Sudarat Tuntivivat, "Performance Evaluation of Humanities and Social Sciences Scholarship Programs in the Thai Higher Education System," Universal Journal of Educational Research, Vol. 9, No. 6, pp. 1124-1133, 2021. DOI: 10.13189/ujer.2021.090602.

(b): Ungsinun Intarakamhang, Sudarat Tuntivivat (2021). Performance Evaluation of Humanities and Social Sciences Scholarship Programs in the Thai Higher Education System. Universal Journal of Educational Research, 9(6), 1124-1133. DOI: 10.13189/ujer.2021.090602.

Copyright $\bigcirc 2021$ by authors, all rights reserved. Authors agree that this article remains permanently open access under the terms of the Creative Commons Attribution License 4.0 International License

\begin{abstract}
Higher education in Thailand has undergone major changes due to digital disruptions, demographic transitions, and the immense competition which increases the need for continuous education, learning and human resources development. The purposes of this convergent parallel mixed methods study were as follows: (1) to monitor and evaluate humanities and social sciences in scholarship programs in the Thai higher education system; (2) to assess the outcome and the impact of the humanities and social sciences scholarship program; and (3) to provide feedback on how to increase the performance of the program. The quantitative design employed a set of surveys consisting of 114 items with a Cronbach's alpha reliability between .956-.996. The sample consisted of 208 faculty members across Thailand in the humanities and social sciences who received government scholarships. The qualitative data purposively conducted interviews with 27 participants from 12 different universities. The quantitative research showed that the factors related to the program outcomes and impact identified a significant relationship between the program Context, Input, Process, and Outcome and with high correlation coefficient (r) at $.579, .522, .459$ and .779 , respectively. The qualitative research presented comprehensive recommendations to improve the performance of humanities and social science faculty members.
\end{abstract}

Keywords Monitoring, Evaluation, Performance, Scholarship, Higher Education

\section{Introduction}

Higher Education in Thailand has undergone dramatic changes over decades due to a major shift in educational policies, which include massification [1], internationalization [2] and privatization [3]. Moreover, the socioeconomic and demographic transformation of the Thai society, including the rapid rise of an ageing population and increased workplace diversity, which greatly affects the dynamic of the higher education system of Thailand [4]. The new generation of college students is varied in terms of both demographic information and geographic locations due to a globalized world with advancements in terms of information technology and artificial intelligence [5]. Likewise, the use of information technology can disrupt curriculum development, teaching practices, and learning environments in higher education [6].

It is hard to deny that the number of traditional enrollments in higher education have been impacted by technology [5] and global competition [7]. Some social science and humanities majors are less vulnerable because their faculties have updated and transformed their curricula and teaching practices to fit with digital disruption and globalized economy, so it is harder for it to be replaced by technology [8]. However, there has been a drastic drop in 
enrollment in social sciences and humanities majors since routine jobs will be replaced by various technologies [9]. This phenomenon has demonstrated a negative effect on work engagement [10] and the well-being of faculty members [11]. Therefore, it is vital for the higher education commission and other government agencies to offer greater human resources strategies to foster well-being and performance for faculty members to become more competitive in the Volatility, Uncertainty, Complexity and Ambiguity (VUCA) learning and teaching environment $[12,13]$.

Human resources development in higher education is one of the key competitive advantages for higher education in VUCA World [14, 15]. Many higher education institutions have adopted new management strategies for a better performance, including fostering leadership, motivation, and continuous education $[16,7]$. However, previous studies have showed that the assessment of the performance of human resources development remained an issue of global concern [17]. It has been influenced by various aspects including globalization, dynamic environments, workforce diversities, and technological transformations [18]. Furthermore, many studies suggested that there is no one-fits-all approach to the assessment of performance of human resources development, but the monitoring and evaluation is an important tool, which can be used to guide human resources to enhance performance in higher education $[19,20]$. Moreover, numerous studies support the idea that monitoring and evaluation had a significant impact on academic motivation [21]; organizational effectiveness [22]; and academic performance [23]. Nonetheless, there is a little evidence on the monitoring and evaluation of performance of human resources development in the Thai higher education system [3]. Hence, this study intends to monitor and evaluate the impact of national and international humanities and social sciences scholarship programs in the Office of the Higher Education Commission (OHEC).

\section{Research Objectives}

1. To monitor and evaluate the humanities and social sciences scholarship program in the Thai higher education system.

2. To assess the outcomes and the impact of a humanities and social sciences scholarship program in the Thai higher education system.

3. To provide feedback on how to increase performance in the humanities and social sciences program.

\section{Literature Review}

\section{Humanities and Social Sciences in Thai Higher Education System}

Humanities and Social Sciences in the Higher Education system has played an essential role in social, economic, and human resources development in Thailand. The higher education enrolments in Thailand were heavily skewed towards the humanities and social sciences. The ratio of student enrollment in humanity and social sciences compared to science, technology, engineering, and mathematics subjects is $3: 1$ from 2015 to 2018 [24]. However, the mismatch between labor supply and demand issues have become a national phenomenon due to the educational level of graduates not corresponding with the needs of the current labor market [25]. Consequently, there is an increased pressure on universities to promote science, technology, engineering, and mathematical subjects to develop a strong scientific knowledge and innovation to compete in the world market [26].

In 2003, the Office of the Higher Education Commission (OHEC) was established. The rationale for establishing the OHEC was to manage public and private universities, to improve communication between basic and higher education; providing professional training, and supporting university personnel. Therefore, the OHEC initiated a scholarship program for postgraduate degrees in the humanities and social sciences [27]. The purpose of this scholarship program is better staff exchange and degree recognition both within Thailand and internationally, as well as to provide specific education for faculty members in highly specialized fields of the humanities and social sciences. Based on the data from 2009 to 2014, there were a total of 605 faculty members who received scholarships, which were divided into 444 faculty members who studied aboard and 161 faculty members who studied in Thailand. Nonetheless, there was no empirical evidence on how this scholarship program has been implemented and monitored [3]. Hence, the purpose of this research is to monitor and evaluate humanities and social sciences scholarship programs under OHEC management.

\section{Theoretical Framework}

This research has adopted a logic model as its theoretical framework. A logic model describes program action by explaining the sequence of actions that link program investments to results. The logic model consisted of five components: (1) the situation is an issue that the program addresses within a situation from which priorities are set; (2) the inputs are resources that the program takes in, including the quality of the candidates, scholarship agreement, curricula, budget, time and facilitation; (3) the steps taken in the process included recruitment, selection, orientation, monitoring and evaluation, and extra-curricular activities; (4) the outputs were the tangible results of the processes in the program, such as attitudes toward the program, knowledge, skill, and ability; and (5) the outcomes are changes among individuals or organizations, including performance, development and satisfaction with the program. The conceptual framework is developed from the theoretical background, as presented in Figure 1. 


\section{Conceptual Framework}

The monitoring and evaluation of a scholarship program for humanities and social sciences in the Thai higher education system applied a CIPP evaluation model developed by [28] which required the evaluation of the context, input, process and the outcomes of the program.

\section{Qualitative Research Design by in-depth interviews with 27 participants includes:}

1. Interviewing two different groups of scholarship recipients: (1) current students and (2) current university workers

2. Interviewing management at the universities where the scholarship recipients work.

3. Interviewing the supervisors of the scholarship recipients.

4. Interviewing staff at the Office of the Civil Service Commission, who are responsible for taking care of scholarship recipients in Thailand and aboard.

\section{Results of Qualitative Research}

- Comprehensive feedback to increase performance of humanities and social science programs, including instructional management, research activities, academic networks, and a passion for working in higher education.

Policy Recommendations for performance improvement

\section{Quantitative Research Design}

\section{Evaluation of Context}

- Achieve program objectives' goals

- Quality of Human Capital

- Alignment with policy

- Human Resources

Development

- Model of Humanities and

Social Sciences

\section{Input}

- Quality of the Candidates

- Scholarship Agreement

- Curricula

- Budget

\section{Process}

- Recruitment

- Selection

- Hiring/Contract Signing

- Orientation

- Monitoring and Evaluation of

Program Management

- Monitoring and Evaluation of

Scholarship Recipients

- Extra-curricular activities

- Succession Plans

- Monitoring and Evaluation

- Participation

Figure 1. Conceptual Framework

\section{Short-Medium Output-}

\section{Outcome}

- Attitudes toward the program

- In-depth knowledge

- Academic skills/ability

- 21 $1^{\text {t }}$ Century Skills

- Inspiration to give to society

Long-term Outcome-Impact

- Study/Job Performance

- Knowiedge and Ability Utilization

- Professional/Self Development

- Networking/Utilization

- Strengthening the workplace

- Satisfaction with program

- Return on investment 


\section{Methodology}

\section{Research design and Data collection}

The mixed-method study applied the convergent parallel design in which quantitative and qualitative research were conducted equally in the same phase of the research process, independently analyzed and interpreted the results [29].

\section{Qualitative Research}

\section{Participants}

The participants in qualitative design consisted of 27 participants from 12 universities across Thailand, including the following: (1) scholarship recipients who are either current scholarship recipients and former scholarship recipients who currently are employed (12 people); (2) management and representatives of universities where scholarship recipients have worked (11 people); and (3) Civil Service Commission officers who oversee scholarship recipients (4 people).

\section{Instruments}

There were two types of instruments, which were as follows: (1) three sets of semi-structured interview guidelines were applied to collect data from both current scholarship recipients, former OHEC scholarship recipients of management, representatives of universities, and Civil Service Commission officers; and (2) observation guidelines were applied for observing the contexts related to aspects of academic institutes for supporting information and to verify the data obtained from the interview guidelines.

\section{Data Analysis and Credibility}

The data analysis consisted of content analysis, which was used to analyze situations, key success factors, barriers of an excellence scholarship program for humanities and social sciences in the Thai higher education system. The credibility inspection for this study can be divided into two types: internal and external. Internal credibility was carried out to confirm that the data was analyzed appropriately and that the procedures for data analysis were rechecked. External credibility was performed using triangulation: (1) data triangulation for collecting data from various spaces and people; (2) researcher triangulation involving multiple researchers in an investigation; and (3) methodological triangulation using more than one option to gather data, such as desk reviews, in-depth interviews, and observations.

\section{Quantitative Research}

\section{Participants}

The quantitative design conducted a cross-sectional survey on the opinions and behaviors of 208 scholarship recipients from 493 scholarship recipients in Thailand and aboard who were keen to participate in the data collection from the 2007-2018 fiscal years, as presented in Table 1.

Table 1. Scholarship recipients

\begin{tabular}{|c|c|c|c|c|c|}
\hline $\begin{array}{c}\text { Years of Study Master } \\
\text { or Ph.D. }\end{array}$ & $\begin{array}{c}\text { Study in } \\
\text { Thailand } \\
\text { (Persons) }\end{array}$ & $\begin{array}{c}\text { Study } \\
\text { Aboard (Persons) }\end{array}$ & $\begin{array}{c}\text { Substitute } \\
\text { (Persons) }\end{array}$ & Total Populations & Sample \\
\hline 2009 & 8 & - & - & 8 \\
\hline 2010 & 20 & 49 & - & 69 \\
\hline 2011 & 15 & 44 & - & 59 \\
\hline 2012 & 21 & 53 & - & 74 \\
208 \\
Scholarship \\
Recipients \\
\hline 2013 & 19 & 85 & - & 104 \\
\hline 2014 & - & 55 & - & 55 \\
\end{tabular}




\section{Instruments}

The questionnaires consisted of demographic information, context, input, process, outputs, outcomes, planning, recruiting and selection, institutionalizing, development, motivation, monitoring, and evaluation dimensions. The questionnaires had a total of 114 items, with a Cronbach's alpha reliability between .956-.996.

\section{Data Analysis}

This research applied the CIPP model developed by Stufflebleam and Shinkfield (2007) and the Logic model developed by Pankratz (2010) to create indicators relevant to the research context, consisting of Context, Input, Process, Outcome, and Impact. Descriptive statistics is used in data analysis to provide valuable information about variables, investigate relationships between variables, and compare factors between different demographic and social groups.

\section{Research ethics}

This research was ethically considered and approved by the Institutional Review Board: IRB Srinakharinwirot University documented SWUEC No. 428/61. Prior to data collection, the researchers informed the subjects about the research using a participant information sheet. The subjects agreed and signed a consent form. The researchers were aware of the importance of the privacy of the informants, so the information was kept confidential to avoid impacts, disturbances, damages to performance, or any other negative impacts. The researchers used appropriate access to collect data and only transcribed the statements given by the informants.

\section{Findings}

1. Monitoring and evaluation of an excellence scholarship program of humanities and social sciences in the Thai higher education system

The data information from OHEC revealed that the scholarship recipients who completed their Master's and Doctoral education were 605 participants from 1,116 scholarship recipients, which could be quantified with descriptive statistics at $52.16 \%$, in the fiscal years of 2007-2014. The scholarship recipients could be divided into 444 international scholarship and 161 national programs in four main degrees, consisting of social sciences, humanities, liberal arts, architecture and other fields, according to policy needs, such as linguistics, geography, environmental management, tourism management, and integrated logistics management. The barriers to performance of scholarship recipients included study pressure, delayed graduation, difficult life adjustments in foreign countries, a lack of continuous monitoring of progression from affiliated universities and the Office of the Higher Education Commission, an unsuitable budget created without considering the cost-of-living adjustments necessary for living abroad, and the complication of paperwork systems between the Office of the Higher Education Commission and the Office of the Civil Service Commission.

\section{Assess the outcome and impact of the program in the human resources development of Humanities and Social Sciences in the higher education system.}

H1: What are the relationships between the factors associated with performance?

Table 1. The relationship of factors related to the outcome of the program and the impact of the project.

\begin{tabular}{|c|c|c|c|c|c|}
\hline Factors & Context & Input & Process & Outcome & Impact \\
\hline 1. Context & 1 & & & & \\
\hline 2. Input & $.602^{* *}$ & 1 & & & \\
\hline 3. Process & $.577^{* *}$ & $.813^{* *}$ & 1 & & \\
\hline 4. Output-Achievement & $.578^{* *}$ & $.471^{* *}$ & $.420^{* *}$ & 1 & \\
\hline 5. Outcome-Impact & $.579^{* *}$ & $.522^{* *}$ & $.459^{* *}$ & $.779^{* *}$ & 1 \\
\hline
\end{tabular}

$$
* * \mathrm{p}<.01
$$


The opinions of scholarship recipients that participated in the scholarship program of humanities and social sciences in the Thai higher education system are that the relationships between the contextual factors (the objectives of projects, the quality of human capital, alignment with government policy, a human resources development model of humanities and the social sciences); the input factors (the quality of the candidates, the scholarship agreement/conditions, curricula, budget and time); the process factors (recruitment and selection, contract signing, orientation, the monitoring and evaluation of program management, the monitoring and evaluation of scholarship recipients, extra-curricular activities, succession plans, monitoring and evaluation); the outcomes (attitudes towards the program and Thailand, in-depth knowledge of the subject, academic skill and ability, twenty-first century skills, and the inspiration to give to society); impact (job performance and study performance, knowledge and ability utilization, self-development and career progression, networking and utilization, the strengthening of the workplace, the satisfaction with the program, and return on investment to university and society) with a high correlation coefficient $(\mathrm{r})$ at $.579, .522, .459$ and .779 respectively and program context, input, process have a significant relationship with program outcomes with a high correlation coefficient $(\mathrm{r})$ at $.578, .471$, and .420 , respectively.

H2: What are the differences between the mean of context, input, process, outcome and impact from different groups of scholars?

Table 2 demonstrates the opinions of scholarship recipients from all and each of the dimensions (context, input, process, outcome, and impact) of humanities and social sciences human resources development programs among different groups of female and male scholarship recipients of different genders and different groups of affiliated universities between research and non-research universities. As shown in the results, female scholarship recipients had higher opinions of the program in terms of context, input, process, outcome, and impact than male scholarship recipients. However, the scholarship recipients from research universities had higher opinions of outcome-impact dimensions than scholarship recipients from non-research universities.

Table 2. Results of comparing the means of factors related to human resources development among scholarship recipients in different groups.

\begin{tabular}{|c|c|c|c|c|c|c|c|c|}
\hline Factors & & & $\mathbf{N}$ & Mean (SD) & T-test & $\begin{array}{c}\text { Variance } \\
\text { Mean } \\
\end{array}$ & $\begin{array}{c}\text { Lower } \\
95 \%\end{array}$ & CL-Upper \\
\hline \multirow{4}{*}{$\begin{array}{l}\text { Factors of } 5 \\
\text { Dimensions }\end{array}$} & \multirow{2}{*}{ Gender } & Male & 86 & $3.78(.54)$ & 64.37 & $3.78 *$ & 3.67 & 3.90 \\
\hline & & Female & 122 & $3.84(.50)$ & 84.18 & $3.84 *$ & 3.75 & 3.93 \\
\hline & \multirow{2}{*}{$\begin{array}{c}\text { Affiliated } \\
\text { Universities }\end{array}$} & Research & 75 & $3.83(.42)$ & 79.50 & $3.83 *$ & 3.73 & 3.92 \\
\hline & & No Research & 133 & $3.81(.57)$ & 76.76 & $3.81 \%$ & 3.71 & 3.91 \\
\hline \multirow{4}{*}{ Context } & \multirow{2}{*}{ Gender } & Male & 86 & $3.83(.70)$ & 50.55 & $3.83 *$ & 3.68 & 3.98 \\
\hline & & Female & 122 & $3.94(.57)$ & 76.09 & $3.94 *$ & 3.84 & 4.05 \\
\hline & \multirow{2}{*}{$\begin{array}{c}\text { Affiliated } \\
\text { Universities }\end{array}$} & Research & 75 & $3.90(.57)$ & 59.36 & $3.90 *$ & 3.77 & 4.03 \\
\hline & & No Research & 133 & $3.90(.66)$ & 67.59 & $3.90 \%$ & 3.78 & 4.01 \\
\hline \multirow{4}{*}{ Input } & \multirow{2}{*}{ Gender } & Male & 86 & $3.53(.79)$ & 41.34 & $3.53 *$ & 3.36 & 3.70 \\
\hline & & Female & 122 & $3.58(.64)$ & 61.54 & $3.58 *$ & 3.46 & 3.69 \\
\hline & \multirow{2}{*}{$\begin{array}{c}\text { Affiliated } \\
\text { Universities }\end{array}$} & Research & 75 & $3.62(.62)$ & 50.56 & $3.62 *$ & 3.48 & 3.76 \\
\hline & & No Research & 133 & $3.52(.75)$ & 54.12 & $3.52 \%$ & 3.39 & 3.65 \\
\hline \multirow{4}{*}{ Process } & \multirow{2}{*}{ Gender } & Male & 86 & $3.20(.86)$ & 34.43 & $3.20 *$ & 3.02 & 3.39 \\
\hline & & Female & 122 & $3.36(.78)$ & 47.87 & $3.36^{*}$ & 3.22 & 3.50 \\
\hline & \multirow{2}{*}{$\begin{array}{c}\text { Affiliated } \\
\text { Universities }\end{array}$} & Research & 75 & 3.25 (.67) & 41.90 & $3.25 *$ & 3.10 & 3.41 \\
\hline & & No Research & 133 & 3.32 (.89) & 43.22 & $3.32 \%$ & 3.17 & 3.48 \\
\hline \multirow[t]{4}{*}{$\begin{array}{c}\text { Output- } \\
\text { achievement }\end{array}$} & \multirow[t]{2}{*}{ Gender } & Male & 86 & $4.30(.59)$ & 67.16 & $4.30 *$ & 4.17 & 4.43 \\
\hline & & Female & 122 & $4.33(.43)$ & 110.44 & $4.33 *$ & 4.25 & 4.41 \\
\hline & \multirow{2}{*}{$\begin{array}{c}\text { Affiliated } \\
\text { Universities }\end{array}$} & Research & 75 & $4.37(.39)$ & 96.86 & $4.37 *$ & 4.28 & 4.46 \\
\hline & & No Research & 133 & $4.29(.56)$ & 88.66 & $4.29 *$ & 4.19 & 4.38 \\
\hline \multirow[t]{4}{*}{ Outcome-Impact } & \multirow{2}{*}{ Gender } & Male & 86 & $4.16(.67)$ & 57.66 & $4.16 *$ & 4.01 & 4.30 \\
\hline & & Female & 122 & $4.13(.56)$ & 81.78 & $4.13 *$ & 4.03 & 4.23 \\
\hline & \multirow{2}{*}{$\begin{array}{c}\text { Affiliated } \\
\text { Universities }\end{array}$} & Research & 75 & $4.17(.48)$ & 74.98 & $4.17 *$ & 4.05 & 4.28 \\
\hline & & No Research & 133 & $4.13(.67)$ & 71.52 & $4.13 *$ & 4.01 & 4.24 \\
\hline
\end{tabular}


Table 3. Results of Comparing Means of Opinions on Human Resources Development Program of Scholarship Recipients from Different Groups of Scholars

\begin{tabular}{|c|c|c|c|c|c|c|}
\hline groups & $\begin{array}{c}\text { General } \\
\text { Information }\end{array}$ & $\mathbf{N}$ & Mean (SD) & \multicolumn{3}{|c|}{$\begin{array}{c}\text { Result of Compare Means of } \\
\text { Opinions on Program }\end{array}$} \\
\hline \multirow{4}{*}{$\begin{array}{l}\text { 1. Age Range } \\
(F=12.94 *)\end{array}$} & & & & 21-30 Y & $31-40 \mathrm{Y}$ & $41-60 \mathrm{Y}$ \\
\hline & 21-30 Y & 38 & $3.59(.42)$ & - & -.18 & $-.51 *$ \\
\hline & $31-40 \mathrm{Y}$ & 119 & $3.77(.49)$ & & - & $-.33^{*}$ \\
\hline & $41-60 \mathrm{Y}$ & 51 & $4.10(.54)$ & & & - \\
\hline \multirow{4}{*}{$\begin{array}{l}2 \text { Tenure Range } \\
(\mathbf{F}=\mathbf{1 1 . 6 8 *})\end{array}$} & & & & 0-10 Y & $11-20 \mathrm{Y}$ & 21-30 Y \\
\hline & $0-10 \mathrm{Y}$ & 155 & $3.72(.47)$ & - & $-.35 *$ & $-.63^{*}$ \\
\hline & $11-20 \mathrm{Y}$ & 49 & $4.07(.58)$ & & - & -.28 \\
\hline & 21-30 Y & 4 & $4.35(.31)$ & & & - \\
\hline \multirow{4}{*}{$\begin{array}{l}\text { 3. Job Description } \\
(\mathbf{F}=\mathbf{1 . 5 3})\end{array}$} & & & & Manage & Teach & Research \\
\hline & Management & 2 & $3.65(.33)$ & - & -.18 & .23 \\
\hline & Teach & 199 & $3.83(.53)$ & & - & .41 \\
\hline & Research & 7 & $3.42(.50)$ & & & - \\
\hline \multirow{4}{*}{$\begin{array}{l}\text { 4. Academic } \\
\text { Position } \\
\left(\mathbf{F}=\mathbf{5 . 6 7 ^ { * } )}\right.\end{array}$} & & & & Assoc. Prof & $\begin{array}{l}\text { Assis } \\
\text { Prof }\end{array}$ & Lecturer \\
\hline & Assoc. Prof. & 2 & 4.37 (.17) & - & $.43 *$ & $.49^{*}$ \\
\hline & Asst. Prof. & 32 & $3.94(.57)$ & & - & .07 \\
\hline & Lecturer & 166 & $3.88(.51)$ & & & - \\
\hline
\end{tabular}

Table 3 shows the results of comparing the means of opinions on a human resources development program of scholarship recipients from different group of scholars of age $\left(\mathrm{F}=12.94^{*}\right)$ tenure $\left(\mathrm{F}=11.68^{*}\right)$ and academic position $\left(\mathrm{F}=5.67^{*}\right)$ and statistically significant at a level of .05 in terms of the opinions of scholarship recipients regarding job descriptions $(F=1.53)$. The results of the t-test on age found that the variance of age range among the 21-30 year old participants and 40-60 year-old participants (3.59 and 4.10, respectively); 31-40 year old and 41-60 year old (3.77 and 4.10 , respectively); the variance of tenure from $0-10$ year old and 11- 20 year old (3.72 and 4.07, respectively) and 0-10 year old and 21-30 year old (3.72 and 4.35, respectively) and academic positions, including associate professors, lecturers (4.37 and 3.88, respectively) and associate and assistant professors (4.37 and 3.94, respectively).

\section{Provide feedback to increase performance in humanities and social science programs.}

The feedback on qualitative research increased the performance of the humanities and social science program, including instructional management, research activities, academic network, and a passion for working in higher education.

Instructional Management is a condition that helps to promote teaching capabilities, including promoting practical experience and opportunities to exchange of ideas from real-world situations to the teaching environment. This will bring more confidence and clarity to teaching and classroom instruction. One communication lecturer claimed: "As we gain experience from real work, it makes us more confident that we can teach and explain to students better". Moreover, some exposure and study abroad experience can give opportunities for professional development and self-improvement. This will help some professors to reflect on the current labor market, the creation of an out-of-classroom teaching process, and field studies that emphasize the practical knowledge suitable for Thai students. One economics professor claimed: "I look at the opportunity do new teaching that will meet the labor market; I'm going to integrate this practice with other sciences as the labor market wants. Kids will be able to enjoy learning, and they know what careers they want in the future." Furthermore, it is important to have management promote teaching skills and development capabilities, such as the development of teaching skills from the original textbook-based teaching to modern online teaching. As one dean mentioned: Professors have knowledge in their own fields, but they do not have the teaching skills or they are going to lack teaching skills for certain groups of students. Therefore, we as management need to promote teaching skills and teaching development capabilities. This is in the plan to be implemented over the next few years."

Research activities allow a faculty member to learn and extend the body of knowledge in their field. Taking part in research can give professors a more positive outlook on their careers and teaching in higher education. A business law professor mentioned: "I am trying to be a teacher and publish research articles to give student a better understanding, which isn't easy. So, I take students to learn and do research in a camp every year." Sharing research 
with seniors or friends from outside universities, both domestically and internationally, conducting research projects or special missions in conjunction with both the government and private sector gives access to professionals and for advice. One linguistics professor stated: "We're conducting research with another professor in China, it's quite a lot of research funding and academic support for our field, which is very good".

Academic Network is the exchange of information and ideas among professors in the same fields, including joint interaction, research collaboration, and agency-level cooperation. One sociology professor mentioned: "Our networking is about building two networks, one internationally and domestically, we're going to create a network at the university level by inviting experts to teach us or invite writers or professionals to share idea or participate in research."

Passion for working in higher education. The commitment to contribute to society, to communicate knowledge to Thai students and the desire to transfer techniques or methods that have been taught overseas to the Thai classroom. One Thai language professor said, "First of all, I want to come back to college to be a professor, because I feel that the completion of my Bachelor's degree, Master's degree, and Ph. D opened up my worldview. I have a lot of theories to apply, and I think that I've to come back to teach, do a lot of collaborative research, and work with people who want to teach in the field."

\section{Discussion and Conclusion}

Higher education systems in Thailand have faced significant changes during the last two decades [1]. The monitoring of human resources development in higher education is an ongoing process that provides information on whether a program is making progress toward its objectives. This study is relevant to the Resource-Based view [35], which provided valuable outcomes for examining the role of human resources performance in gaining a competitive advantage. The resource-based view supports this study in that employee's performance and talent management can enhance the adaption of human resources development [36]. The results found there are factors related to program outcome and impact that found a significant relationship between program context, input, process, and outcome. The results were consistent with [30] setting project goals, and a deliberate effort needs to be made regarding human-related factors. The investment in human resources development through improving the technical capacity of those tasked with the delivery of project results is a prerequisite for consistent project performance [31]. Giving incentives and resources needs skills, time, and equipment to support monitoring and evaluation tasks were reported to be a great motivation.
The more highly motivated individuals reported more benefits of training, which were reflected in the way their projects were performed.

However, there are several barriers of human resources development in humanities and social science including unsuitable budget allocation, complication of paperwork systems and a lack of continuous monitoring and evaluation. As Kim and Mauborgne (2003) pointed out there are distinct barriers restraining human resources development from achieving their performance including cognitive hurdles, resource hurdles, motivational hurdles, and political hurdles [37]. These findings are consistent with [32] the study of the administrative model of the one district one scholarship project in Thailand found several barriers including inadequate time, ineffective management on academic disciplines, and inconsistent monitoring and evaluation of academic achievement. It is consistent with study of [33] on the Czech government scholarship program for students from developing countries that found a lack of quality assessment among scholarship recipients, the incompetency of program management, and a lack of scholarship recipients returning to their home country for impact measurement [33].

In addition, the implementation for human resources development needs to be carefully mapped out and in alignment with strategic human resources management theory, which states that the core responsibility of human resources is to define, plan, develop, engage, utilize, lead and retain talented employees to enhance organizational performance [38]. In this study, the first step is assessing the need for human resources development. The next step is designing human resources development programs with the expected benefits. The final aspect of implementing a human resources development program is continuous research and development, as well as a monitoring and evaluation program. Human resources often develop strategies and structure policies, processes, standards, and systems that enforce the methods developed in a variety of disciplines. The implementation can be conducted by the human resources department or a team effort with other departments [34].

The quantitative findings were consistent with the indicators from the qualitative part of the study. The scholarship recipients emphasized that competency and expertise need to be a priority in continuous learning and development in both instructional management and research activities. They also stressed that human resources monitoring and evaluation of employee motivation, passion, and professional networking, were important factors when assessing project performance. Overall, this study proved that monitoring and the evaluation human resources development was therefore an important factor in predicating organizational performance. Human resources are valuable capital that play a very important role in institutions and contributes evidently to their success [39]. The most successful institutions are those that inspire, 
educate, and monitor their workforce. Human resources development is a systematic process in which individuals and groups are trained to develop new competencies to make them more self-reliant and to improve their efficacy in the fulfillment of institutional goals and policy outcomes.

\section{Policy Recommendations}

This study provided a variety of policy implications and recommendations, as follows: (1) continuous monitoring and follow-up with scholarship recipients; and (2) allocation of funding for research, training, and career development among scholarship recipients after graduation.

\section{Funding}

The author(s) received funding from the Thailand Office of the Higher Education Commission (OHEC).

\section{REFERENCES}

[1] UNESCO "Higher Education and Technical \& Vocational Education Training", http://www.unescobkk.org/education/r esources/resources/education-system-profiles/thailand/highe r-tvet/ (accessed Jan. 31, 2021)

[2] Lavankura P. "Internationalizing Higher Education in Thailand: Government and University Responses," Journal of Studies in International Education, vol. 17, no. 5, pp. 663676, 2013.

[3] Crocco O., "Thai Higher Education: Privatization and Massification," in Education in the Asia-Pacific Region: Issues, Concerns and Prospects, (vol. 42), Springer Nature Singapore Pte Ltd., 2018, pp. 223-255.

[4] Office of the National Economic and Social Development Council, "The Twelfth National Economic and Social Development Plan (2017-2021)", Office of the Prime Minister,

https://www.nesdc.go.th/nesdb_en/ewt_dl_link.php?nid=43 45 (accessed Jan. 15, 2020)

[5] Ma Y., Siau K. L., "Artificial Intelligence Impacts on Higher Education (2018) ", MWAIS 2018, http://aisel.aisnet.org/m wais2018/42, (accessed Jan. 1, 2021)

[6] Flavin M., "Disruptive technologies in higher education," in Research in Learning Technology, vol. 20, 2012. https://doi.org/10.3402/rlt.v20i0.19184.

[7] Waller R., Lemoine P., Mense E., Garretson C., M. Richardson, "Global Higher Education in a VUCA World: Concerns and Projections," Journal of Education and Development, vol. 3, no. 73. 2019.DOI:10.20849/jed.v3i2.6 13.
[8] Rainie L., Anderson J., "The Future of Jobs and Jobs Training", Pew Research Center, http://www.pewinternet.or $\mathrm{g} / 2017 / 05 / 03 /$ the-future-of-jobs-and-jobs-training/ (accessed Jan. 31, 2021)

[9] Jain S. R., Jain, "Role of Artificial Intelligence in Higher Education-An Empirical Investigation," International Journal of Research and Analytical Reviews, vol. 6, no. 2, pp. 144-150, 2019.

[10] Gokhale M. "Work-related quality of life and work engagement of college teachers," Annamalai International Journal of Business Studies \& Research, Special Issue, pp. 60-63, 2015.

[11] Sriprasertsuk A., Tuntivivat S., Leesattrupai C., P. Wongpinpech, "Structural Equation Modeling of Work Well-being of Academic Employees in Autonomous Universities," Warasan Phuettikammasat, vol. 25, no.1, pp.140-164. 2019. http://bsris.swu.ac.th/journal/250162/10.amporn140-164.pdf

[12] Wadhwa R. "New phase of internationalization of higher education and institutional change," Higher Education for the Future, vol. 3, no. 2, pp. 227-246, 2016.

[13] Korsakova T. V. "Higher education in VUCA world: New metaphor of university," European Journal of Interdisciplinary Studies, vol. 5, no. 2, pp. 31-35, 2019.

[14] Elkington S, Glick-Smith J, J. M. Breen., "Visionary Leadership in a Turbulent World: Thriving in the New VUCA Context," Emerald Publishing Limited, 2017. https://books.emeraldinsight.com/page/detail/Visionary-Lea dership-in-a-Turbulent-World/?k=9781787142435 Emerald Publishing Limited

[15] Stewart B, Khare A, Schatz R., "Volatility, Uncertainty, Complexity and Ambiguity in Higher Education", Springer International Publishing Switzerland. https://www.researchg ate.net/publication/294470076 Volatility_Uncertainty_Com plexity_and_Ambiguity_in_Higher_Education (accessed Jan. $15,2021)$

[16] Evans A, E. Chun, "Creating a Tipping Point: Strategic Human Resources in Higher Education: ASHE Higher Education," John Wiley \& Sons Inc, 2012.

[17] Shu-Kun L, "Human Resource Management, 11th Edition International Student Version. By David A. DeCenzo, Stephen P. Robbins and Susan L. Verhulst," Administrative Sciences, MDPI, Open Access Journal, vol. 3, no. 1, pp. 1-2, 2013.

https://ideas.repec.org/a/gam/jadmsc/v3y2013i1p4-5d23675 .html

[18] Huselid M. A., Jackson S. E., R. S. Schuler, “Technical and strategic human resource management effectiveness as determinants of firm performance," Academy of Management Journal, vol. 40, pp. 171-188, 1997.

[19] Tengan C, Anzagira F, Kissi E, Balaara S, A. Anzagira "Factors Affecting Quality Performance of Construction Firms in Ghana: Evidence from Small," Civil and Environmental Research, vol.6, no.5, pp. 18-23. 2014.

[20] Niyivuga B., Otara A., D. Tuyishime, "Monitoring and Evaluation Practices and Academic Staff Motivation: Implications in Higher Education Within Rwandan Context," Sage Open, vol. 1, no. 9, 2019. https://doi.org/10.1177/2158 


\section{4}

[21] Siddique A., Aslam M. D., Khan M., U. Fatima, "Impact of academic leadership on faculty's motivation, and organizational effectiveness in higher education system," International Journal of Business and Social Science, vol. 2, pp. 184-191, 2011.

[22] Chukwu C. L., Mezieobi D., Uguwanyi B. E., C. Okpoebo, "Monitoring and Evaluation on Effective Delivery of Social Studies for Improved Academic Performance," Review of European Studies, vol. 11, no. 1, pp. 175-182, 2019. DOI:10.5539/res.v11n 1 p 175

[23] Office of the Higher Education Commission, "Higher Educational Statistics", http://www.info.mua.go.th/info/ (access Jan. 1, 2021)

[24] Eichhorst W., Rodríguez-Planas N., Schmidl R., Zimmermann, K., "A Roadmap toVocational education Systems around the World", IZA, http://ftp.iza.org/dp7110.p df (accessed Jan. 23, 2021)

[25] Office of National Education Council, “An annual report year 2016 of the Office of National Education Council: The integration to national education plan", Office of National Education Council.http://www.oic.go.th/fileweb/cabinfocen ter6/drawer050/general/data0000/00000028.pdf (accessed Jan. 15, 2021)

[26] Office of the Higher Education Commission [OHEC], "Thai higher education: Policy \& issues," OHEC, 2011.

[27] Stufflebeam D L, A. J. Shinkfield, "Evaluation theory, models and applications," CA Jossey-Bass, 2007.

[28] Creswell J W, V. L. Plano Clark, "Designing and Conducting Mixed Methods Research,” (2nd ed.), Sage Publications, 2011.

[29] Oladipo J, A. D. Sani, "Strategic Human Resource Management and Organizational Performance in the Nigerian Manufacturing Sector: An Empirical Investigation,"
International Journal of Business and Management, vol. 6, no. 9, 2011. DOI: 10.5539/ijbm.v6n9p46

[30] Chand M, A. A. Katou, "The impact of HRM practices on organizational performance in the Indian hotel industry," Employee Relations, vol. 29, no. 6, pp. 576-594, 2007.

[31] Chittradub S., Keawearn S., Sunanlikanon, N., J. Masantei, "The Study of the Administrative Model of the One District One Scholarship Project," Journal of Education, vol. 46, no. 2, pp. 197-217, 2018.

[32] Němečková T, P. Krylova, 2014. "The Czech government scholarship programme for students from developing countries - Evaluation findings and policy reflections," Evaluation and Program Planning, Elsevier, vol. 43, no. C, pp.83-92, 2014.

[33] Kumar V., Ali M., S. Kumar, "Framework for Implementing Human Resource Development Programmes in higher educational institutions," International Journal of Engineering and Management Sciences, vol. 4, no. 1, pp. 36-39, 2013.

[34] Barney J, "Firm resources and sustained competitive advantage," Journal of Management, vol. 17, pp. 99-120, 1991.

[35] Tetik S, (2017). "Talent Management: A Review of Theoretical Perspectives and a Guideline for Practitioners," Nile Journal of Business and Economics, vol. 2, no. 40, DOI: 10.20321/nilejbe.v2i4.77.

[36] Kim C., M. Renee, "Tipping Point Leadership," Harvard Business Review, https://hbr.org/2003/04/tipping-point-lead ership (accessed Mar. 20, 2021)

[37] Rees G., P. Smith, (Eds.) "Strategic Human Resource Management: An International Perspective (2nd ed.)," SAGE Publications Ltd,https://uk.sagepub.com/en-gb/eur/st rategic-human-resource-management/book $249141 \% 20 \#$ des cription (accessed Mar. 20, 2021)

[38] Jackson S E., Schuler R. S., K. Jiang, “An aspirational framework for strategic human resource management," The Academy of Management Annals, vol. 8, pp. 1-56, 2014. 